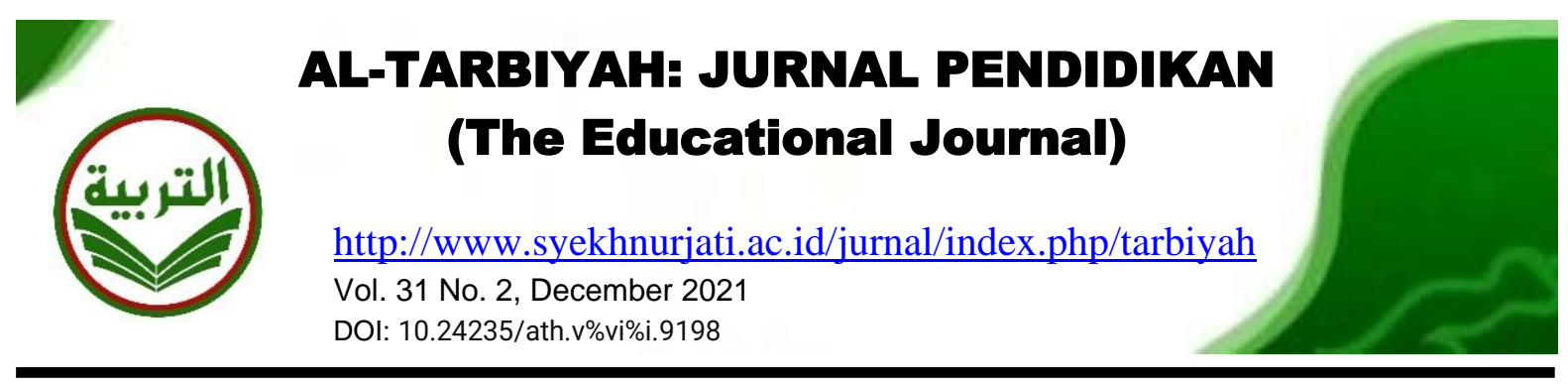

\title{
Revitalisasi Ma'had al-Jami'ah IAIN Pekalongan Dalam Menyongsong Kampus Merdeka Belajar
}

\author{
Muhammad Mufid ${ }^{1}$, Jainul Arifin ${ }^{2}$ \\ 1,2, IAIN Pekalongan \\ e-mail: m.mufid@iainpekalongan.ac.id,
}

\begin{abstract}
Abstrak
Kebijakan merdeka belajar kampus merdeka dengan program pertukaran pelajar dan praktik kerja merupakan transformasi refleksi dan aksi dalam tubuh perguruan tinggi keagaman islam. Di satu sisi kebijakan tersebut berupaya merespon era disrupsi dengan meningkatkan mutu lulusan. Di sisi yang yang lain kebijakan tersebut mereduksi distingsi perguruan tinggi keagaman islam sebagai pusat kajian pendalaman ilmu-ilmu keislaman. Untuk itu tujuan dalam penelitian ini adalah mengungkap gerak ma'had al-jami'ah sebagai basis tafaqquh fiddin dalam menyongsong merdeka belajar kampus merdeka pada perguruan tinggi keagamaan islam. Penelitian ini menggunakan metode kualitatif library research dengan pendekatan deskriptif analitik. Hasil penelitian menunjukkan beberapa hal penting. Pertama, Peningkatan Kompetensi lulusan melalui program Dirasah Tahsin alQur'an, Dirasah Tahfidz al-Qur'an, Dirasah Kitab Turast, program Praktikum Ibadah-Tilawah, program Pesantren Mitra Mahasantri, program Mahasiswa Cendekia. Kedua, adanya pengintegrasian muatan mata kuliah keilmuan keislaman dalam kebijakan merdeka belajar kampus merdeka. Ketiga, Penguatan mutu lulusan yang kuat dalam metodologi ilmiah dan sikap moderat dalam beragama dengan menjalin koneksi dan kerjasama dengan para ilmuwan, pondok pesantren, forum komunikasi diniyah takmiliyah.
\end{abstract}

Kata kunci: ma'had al-jami'ah, kampus merdeka belajar, perguruan tinggi keagamaan islam

\begin{abstract}
The policy of independent campus freedom to learn through student exchange programs and work practices is a transformation of reflection and action within Islamic religious universities. On the one hand, the policy seeks to respond to the era of disruption by improving the quality of graduates. On the other hand, it reduces the distinction of Islamic religious universities as centers of study to learn Islamic sciences. Because of that, the purpose of this study was to reveal the movement of ma'had al-jami'ah as the basis for tafaqquh fiddin to prepare for independent campus, freedom to learn at Islamic religious universities. This study used a qualitative library research method with an analytical descriptive approach. The results of the study show some important points. First, the improvement of the
\end{abstract}


graduates' competence through Dirasah Tahsin Al-Qur'an program, Dirasah Tahfidz Al-Qur'an, Dirasah Kitab Turas, Praktikum Ibadah-Tilawah, Pesantren Mitra Mahasantri, and Mahasiswa Cendikia programs. Second, there is integration of the Islamic science content courses in independent campus freedom to learn policy. Third, the reinforcement of graduates' quality who master scientific methodologies and religious moderation attitudes well by establishing connections and collaborations with scientists, Islamic boarding schools, and diniyah takmiliyah communication. forums.

Keywords: ma'had al-jami'ah, independent campus freedom to learn, Islamic religious universities

\section{PENDAHULUAN}

Munculnya fenomena disruptive innovasion di era revolusi industri telah menggeser tatanan sistem dan pola pikir masyarakat diberbagai bidang termasuk didalamya bidang pendidikan. Perubahan ekonomi, sosial, dan budaya masyarakat menimbulkan tuntutan semakin tinggi terhadap standar mutu pendidikan, terlebih profesi berbasis digital, spesialisasi skill, gaya hidup konsumtivisme, rasionalisasi pertumbuhan ekonomi, pemiskinan spiritual dan falsafah hidup yang menyertai kemajuan teknologi informasi memaksa IAIN Pekalongan mampu merespon secara cepat dan tepat untuk membekali mahasiswa yang siap bersahabat dengan tantangan globalisasi tanpa menghilangkan jejak budaya bangsa.

Dalam dinamika perkembangan masyarakat, faktor kesejahteraan perekonomian menjadi faktor penentu bagi generasi milenial untuk melanjutkan studi pendidikanya, bahkan bisa dikatakan barometer Perguruan Tinggi yang bermutu adalah yang mampu menyerap lulusanya terjun langsung di dunia kerja. Semua tidak menginginkan setelah lulus menjadi pengangguran. Bila melihat data Badan Pusat Statistik (BPS) bulan Februari 2021 menunjukkan bahwa jumlah pengangguran di kalangan terdidik tingkat universitas mencapai $6,97 \%$. Persentase pengangguran meningkat bila dibandingkan dengan bulan Februari tahun 2020 sebesar 5,70 \% (https://www.bps.go.id) ${ }^{1}$. Dampak dari pengangguran tentu saja menimbulkan problem yang bukan hanya tertuju pada bidang ekonomi saja melainkan mengarah juga pada bidang pendidikan. Imbas dalam pendidikan seperti putus sekolah, ketidakpercayaan masyarakat terhadap kualitas sekolah, terjadinya diferensiasi antara pendidikan dengan ekonomi sosial.

Untuk itu, hadirnya kebijakan Kampus Merdeka belajar merupakan strategi peningkatan mutu pendidikan untuk mampu menjawab tuntunan global dan kompetitif di tingkat nasional dan internasional yang terfokus pada kemerdekaan sumber daya mahasiswa. Baro'ah memaparkan rendahnya kualitas pendidikan yang berhadapan dengan persaingan kreativitas, inovasi dan kecepatan, membutuhkan strategi pendekatan dan kebijakan khusus dalam sistem pendidikan yang mampu meningkatkan layanan dan mutu pendidikan. Melalui kebijakan kampus merdeka belajar yang memiliki karakter

\footnotetext{
1 https://www.bps.go.id/subject/6/tenagakerja.html\#subjekViewTab4
} 
peningkatan kompetensi lulusan baik hard skills maupun soft skills yang diharapkan memberikan konstribusi lebih terhadap sumber daya manusia yang energik, berkualitas dan menjadi aset penting untuk mengisi pembangunan diberbagai bidang (Baro'ah, 2020)

Melalui kebijakan Kampus Merdeka Belajar mahasiswa memperoleh kesempatan hak belajar untuk melaksanakan pembelajaran di Perguruan Tinggi yang berbeda pada program studi yang sama selama 1 semester atau sebanyak 20 SKS (Dirjen Dikti Kemendikbud, 2020). Kebijakan ini memberikan peluang kepada mahasiswa untuk memperluas wawasan pengetahuan, pengembangan kreativitas, serta peningkatan kompetensi keahlian. Hal ini merupakan bekal penting bagi mahasiswa mengingat dinamika lapangan kerja yang semakin kompetitif berbanding lurus dengan profesionalitas skill kemampuan mahasiswa tersebut dalam proses pembelajaran.

Bagi IAIN Pekalongan tentu saja kebijakan ini membawa transformasi baru dalam sistem pembelajaran. Pengembangan kurikulum, muatan mata kuliah lintas prodi, ekuvalensi praktikum perlu penyesuaian ulang yang selaras dengan implementasi kampus merdeka belajar. Namun demikian, tugas pokok IAIN Pekalongan untuk menyiapkan lulusan yang kompeten di bidang kajian keislaman, tafaqquh fiddin, tetap menjadi perhatian yang utama. Hal ini perlu ditindaklanjuti dalam langkah kongkrit, apalagi bila melihat input peserta ujian masuk PTKIN lulusan SMA dan SMK lebih banyak dibanding dengan lulusan MA dimana kita ketahui di SMA maupun SMK muatan pelajaran agamanya lebih sedikit dibanding dengan MA. Lulusan SMASMK sebanyak 55,02\% sedangkan lulusan MA sebanyak 41,79\% (https://kemenag.go.id) ${ }^{2}$. Dengan demikian kapasitas pemahaman ilmu-ilmu keislaman bagi mahasiswa baru perlu adanya pembinaan dan standarisasi khususnya di PTKIN yang notabenya sebagai benteng pendalaman kajian ilmu-ilmu keislaman.

Berkaitan dengan hal tersebut, IAIN Pekalongan mengembangkan unit Ma'had al-Jami'ah sebagai transmisi bentuk pelembagaan tradisi keilmuan Pesantren dalam lingkungan kampus. Fungsi penyeleggaraan Ma'had al-Jami'ah adalah memperkuat dasar-dasar dan wawasan keagamaan keislaman (Islam, 2011). Hal ini menarik untuk dikaji dalam kaitanya dengan kebijakan kampus merdeka belajar, karena asumsi umum dunia akademik yang dicirikan dengan kemampuan skill, akal pikiran, kreativitas,sains menawarkan solusi yang relevan dengan dinamika kebutuhan dan perkembangan zaman bersanding dengan dasar agama yang berasal dari keyakinan, bersifat dogmatisdoktrinal, memberikan prinsip dalam menjalani kehidupan. Mencoba menguak, mengurai, memahami cara pandang Ma'had al-Jami'ah dalam menyikapi kebijakan kampus merdeka belajar merupakan hal penting karena berimbas pada bangunan paradigma keilmuan keislaman di IAIN Pekalongan.

\section{METODE PENELITIAN}

Penelitian ini tergolong jenis penelitian kualitatif sifatnya deskriptif karena data yang dianalisis tidak untuk menerima atau menolak hipotesis melainkan hasil analisis itu berupa deskrispi gejala-gejala yang diamati (Subana, n.d.). Dalam hal ini data

\footnotetext{
${ }^{2}$ https://kemenag.go.id/read/menjaga-khittah-ptkimelalui-um-ptkin-6751x.
} 
yang dianalisis yaitu konsep kebijakan kampus merdeka belajar dan aplikasinya dalam lingkup unit Ma'had al-Jamiah. Selanjutnya metode pengumpulan data yang digunakan adalah observasi melalui pengamatan langsung guna melihat fakta yang terjadi yakni sikap unit ma'had aljami'ah berkenaan dengan kebijakan kampus merdeka belajar. Kemudian setelah data terkumpul peneliti menganalisis data dengan tiga tahapan yaitu reduksi data, penyajian data, dan verifikasi penarikan kesimpulan (Moleong, 2017).

Dengan demikian dalam menyusun laporan sebagai kesimpulan data terdapat empat langkah yaitu: Satu, mengumpulkan bahan dasar data berupa bentukkebijakan kampus merdeka belajar dan pandangan unit ma'had al-jami' ah terhadap kebijakan tersebut serta respon gerak ma'had aljami'ah dalam implementasinya. Dua, informasi yang di dapat baik dari wawancara maupun dokumen yang terlalu luas dicari benang merah sesuai garis pokok fokus penelitian. Tiga, informasi tersebut digunakan dalam penelitian didukung dengan informasi-informasi lain yang selaras. Empat, menyimpulkan data sesuai dengan fokus masalah yang telah ditentukan. Setelah diteliti dengan seksama jika diketemukan adanya perbedaan data informasi maka diadakan trianggulasi teknik pemeriksaan keabsahan data (Moleong, 2017).

\section{HASIL DAN PEMBAHASAN}

\section{Pandangan Umum Kebijakan Kampus Merdeka Belajar}

Memasuki era society 5.0 pendidikan islam dihadapkan dengan tantangan baru yang tidak hanya sekedar mengembangkan potensi karakter yang baik melainkan juga mampu menghantarkan peserta didik agar memiliki kemampuan problem solving, critical thingking dan creative skill, sehingga mampu beradaptasi dan berinovasi di lingkungan dunia industri (Khoirin, 2021). Dalam menyongsong kebutuhan tersebut, Menteri Pendidikan dan Kebudayaan (kemendikbud) mencetuskan kebijakan program 'Merdeka Belajar' yang dicanangkan pada semua tingkatan jenjang pendidikan. Adapun untuk tingkat Perguruan Tinggi diberi nama dengan Kampus Merdeka Belajar. Esensi kampus merdeka belajar adalah menelusuri potensi yang dimiliki oleh para dosen dan mahasiswa untuk berkreasi dan berinovasi secara mandiri agar berkualitas dalam kegiatan pembelajaran. Mandiri dalam hal ini tidak sekedar mengikuti birokrasi administrasi pendidikan, melainkan benarbenar memunculkan inovasi pendidikan (Widiyono \& Irfana, Saidatul, 2021).

Program utama kebijakan kampus merdeka belajar antara lain yaitu peralihan sistem akreditasi perguruan tinggi menjadi Perguruan Tinggi Negeri berbadan hukum, kemudahan layanan pembukaan program studi baru, fasilitas hak belajar selama tiga semester berupa kesempatan dua semester mengikuti pembelajaran di luar perguruan tinggi pada program studi yang sama dan kesempatan belajar selama satu semester di dalam perguruan tinggi pada program studi yang berbeda. Dan juga diberikan berbagai penawaran bentuk program kegiatan di luar perguruan tinggi antara lain yaitu pengalaman praktik kerja atau magang di tempat kerja atau industri, melaksanakan pendampingan pengabdian kepada masyarakat desa, pendamping atau asisten pengajar, ikut berpartisipasi dalam penelitian, melakukan projek kewirausahaan, studi pembinaan pasion mahasiswa, dan berkontribusi dalam 
program kemanusiaan(Dirjen Dikti Kemendikbud, 2020).

Kampus merdeka belajar melalui pendekatan student center learning dengan pola pengembangan model pembelajaran yang mensinergikan antara dunia keilmuan dengan dunia kerja merupakan perwujudan dari tujuan sistem pendidikan yakni mewujudkan sumber daya manusia yang bermutu dan berkualitas. Yamin menilai kecenderungan dalam pendidikan di era globalisasi ini menyangkut media dan metode pembelajaran serta sumber daya manusia adalah penguasaan terhadap literasi data, literasi teknologi dan literasi manusia, target ini memiliki kesamaan dengan kebijakan kampus merdeka belajar (Yamin \& Syahrir, 2020). Kebijakan kampus merdeka belajar merupakan kebijakan yang visioner, tujuan besar terciptanya lembaga pendidikan yang tidak birokratis, artinya otonom sehingga terbangunya sistem pembelajaaran yang inovatif berbasis pada minat bakat dan peka terhadap tuntutan dunia modern. Hal ini patut diapresiasi dan dikawal bersama sebagai bentuk aktualisasi kebijakan kampus merdeka belajar.

Sedangkan menurut bahar kebijakan merdeka belajar merupakan upaya mengembalikan literasi pendidikan pada khittahnya, karena salah satu proses kependidikan adalah mewujudkan suasana yang bahagia bagi peserta didik dalam mengembangkan potensinya, sehingga peserta didik literat dalam pengendalian dirinya, dalam keagamaanya, kecerdasan dan keterampilanya (Bahar \& Herli Sundi, 2020). Dengan demikian dapat dikatakan dengan kebijakan kampus merdeka belajar yang memiliki karakter pengembangan potensi diri sebagai bekal penting menjadi alat manajemen untuk mendeteksi atau memetakan kompetensi dengan prospek kerja di lapangan. Dalam hal ini keselarasan pengembangan kurikulum merdeka belajar perlu digalakkan. Keilmuan kebidangan yang berpotensi tinggi di era multidimensi ini perlu disikapi dan dioptimalisasikan.

Poin penting implementasi merdeka belajar adalah mengarahkan segala keterampilan untuk mengurai akar masalah dan mampu mengidentifikasi setiap permasalahan dengan menggunakan kompetensinya. Secara konseptual kemampuan tersebut menurut hafid dikenal dengan High Order Thingking Skills (HOTS), yakni kemampuan kognitif yang lebih tinggi digunakan dalam menghubungkan, mengkomunikasikan dan mengembangkan wawasan pengetahuan serta pengalaman untuk menyelesaikan kompleksitas masalah (Hafid \& Mahsun, 2020). Dengan demikian hasil pembelajaran dari pengembangan kemampuan dan keterampilan kampus merdeka belajar dalam tahap selanjutnya mahasiswa bisa membandingkan dan mengaitkan antara pengetahuan yang didapat dengan pengalaman riil di lapangan sehingga mampu memadukan dan menerapkan strategi yang relevan dengan kebutuhan. Hal ini sekaligus sebagai out come penunjang capaian kualifikasi lulusan.

Dalam tataran praktis kebijakan merdeka belajar direspon positif oleh para praktisi pendidikan. Dalam lingkup pendidikan menengah, para guru menganggap kebijakan merdeka belajar sesuai dengan mekanisme pelaksanaan pembelajaran di sekolah, proses yang berdasarkan kearifan lokal dan optimaliasai sumber daya yang dimiliki sekolahan memberikan iklim belajar yang memicu guru untuk mengeksplorasi cara yang 
terbaik dalam melakukan kegiatan pembelajaran (Prakoso et al., 2021). Sedangkan dalam lingkup pendidikan tinggi, civitas akademika menilai empat point kebijakan kampus merdeka belajar merupakan sebuah perhatian, bentuk kepedulian sekaligus perhatian terhadap sistem perguruan tinggi yang berjalan di Indonesia. Hal ini dapat dipahami mengingat mahasiswa sebagai regenerasi penerus masa depan berdampingan berdampingan dengan era revolusi industri, melalui hak belajar tiga semester di luar prodi diharapakan mahasiswa lebih aktif, kreatif, inovatif, dan terbentuknya kerjasama antar mahasiswa di berbagai perguruan tinggi (Siregar et al., 2020).

\section{Eksistensi Ma'had al-Jami'ah}

Cikal bakal pelembagaan ma'had aljami'ah adalah mensinergikan sistem pembalajaran Pondok Pesantren dengan pembelajaran formal di lingkungan Perguruan Tinggi keagamaan islam. Suardi menuturkan Pesantrenisasi mahasiwa merupakan objek tujuan didirikan Ma'had al-Jami'ah dimana kegiatan-kegiatan pengajian pengkajian ilmu-ilmu keislaman yang sudah berpuluh-puluh tahun diadakan di Pondok Pesantren dipadukan dalam sistem pembelajaran di perguruan tinggi keagamaan islam (Suardi, 2018).Diterapkan tradisi pesantren dalam dunia kampus tidak lain untuk meningkatkan kualitas lulusan perguruan tinggi keagamaan islam sekaligus mempertahankan metodologi keilmuan pesantren dengan mengkompromikan dan mengembangkan model kurikulum yang sesuai dengan kemajuan ilmu pengetahuan dan teknologi dengan tanpa menghilangkan ruh spiritual.

Tradisi pesantren dengan kajian arab pegon dan pengamalan akhlak telah berkontribusi besar dalam penyebaran islam di Indonesia. Implikasi dari pesantren lahir wajah wajah muslim yang ramah berbudaya, berilmu, cinta damai yang menghantarkan kerukunan baik sesama manusia maupun antar umat beragama, memiliki karakter yang tidak hanya masalah teknis dan pragmatis belaka melainkan mengandung unsur kepentingan sosial dan mengkonfirmasi keragaman tradisi dan budaya di Indonesia (Ulyan et al., 2020). Sistem pembelajaran seperti inilah yang akan dipadukan dalam program kegiatan di Ma'had al-Jami'ah. Terlebih dalam pandangan masyarakat umum pemahaman dan penguasaan terhadap kitab turast serta peranggai akhlak yang baik dalam tingkah laku merupakan menjadi barometer kealiman seseorang yang layak menjadi panutan, sehingga pembinaanpembinaan dalam Ma'had al-jami'ah ingin menampilkan mahasiswa yang memiliki pemahaman mendalam ilmu-ilmu keislaman serta bertingkah laku dengan penuh nilai-nilai keadaban.

Ma'had al-Jami'ah merupakan bagian dari reformasi masif dalam tubuh pendidikan islam melalui reorientasi pengembangan kurikulum pesantren dalam tubuh civitas akademika. Keluarnya Peraturan Menteri Agama (PMA) Nomor 13 Tahun 2014 tentang pendidikan agama islam pada pasal 46 paragraf 1 ayat 7 yang menegaskan jenjang al-jami'ah diikuti oleh perguruan tinggi merupakan bentuk pengakuan pemerintah terhadap keberadaan ma'had la-jami'ah sebagai unit pembinaan kajian ilmu-ilmu keislaman.(KemendagRI, 2014). Dan juga Kementrian Agama Republik Indonesia Direktorat Jenderal Pendidikan Islam mengintruksikan dengan segera penyelenggaraan pesantren kampus (ma'had al-jami'ah) di perguruan tinggi keagamaan islam merupakan regulasi yang 
kuat terhadap fungsi dan loyalitas ma'had al-jami'ah (Islam, 2011). Kehadiran ma'had al-jami'ah dalam lingkungan perguruan tinggi keagamaan islam merupakan distingsi ciri pembeda dengan perguruan tinggi umum lainya dalam hal pendalaman kajian ilmu-ilmu keislaman.

Lebih lanjut Jumaeda menuturkan bahwa perguruan tinggi keagamaan islam sebagai pusat pembinaan kecakapan kompetensi mahasiswa baik dari bidang akademik maupun sikap moral spiritual, dirasakan tidak cukup dibangun hanya melalui pembelajaran mata kuliah di kelas yang memiliki bobot sks 2 atau 3 sks dengan 14 kali pertemuan saja, melainkan meniscayakan membutuhkan wadah unit yang bergerak terarah sistematis mendukung perkembangan intelektual dan spiritual mahasiswa, untuk itulah kedatangan ma'had al-jami'ah merupakan strategi dan pilihan yang tepat (Jumaeda, 2017). Hal ini dapat dipahami pentingya ma'had al-jami'ah mengingat kompleksitas muatan ajaran-ajaran yang terkandung dalam agama islam harus benar-benar harus dipelajari secara komprehensif oleh mahasiswa lulusan perguruan tinggi keagamaan islam karena sebagai bekal penting agar memiliki karakter, wawasan, moral agamis yang berguna untuk dirinya, agamnaya, masyarakatya, bangsa dan negaranya.

Secara lebih spesifik tujuan ma'had al-jami'ah dalam memperkuat pemahaman ilmu-ilmu keislaman dapat diperinci dalam 3 bentuk, yaitu: Satu, Ta'aruf fin al-Din yakni memperkenalkan pondasi dasasr agama islam kepada mahasiswa agar memiliki kompetensi keagamaan tingkat dasar, Dua,Ta'alum fi al-Din yakni membimbing mahasiswa berkenaan dengan pemahaman ilmu-ilmu keagamaan islam agar memiliki kemampuan mendalam dan mempraktekkan secara aktif dalam kegiatan-kegiatan kemasyarakatan, Tiga, Tafaqquh fi al-Din yakni membina mahasiswa dalam hal peningkatan dan pengembangan pemahaman ilmu-ilmu keagamaan seacara komprehensid agar dengan kemampuan dan keterampilanya mampu menguraikan ilmu-ilmu keislaman dalam berbagai perspektif serta menjadi pelopor dalam kegiatan keagamaan di masyarakat (Direktorat Pendidikan Tinggi Islam Jenderal Pendidikan Islam Kementerian, 2021). Tiga bentuk pemetaan tersebut dapat dipahami mengingat input mahasiswa dari beragam latar belakang pendidikan dan juga sebagai tahapan pembinaan yang menyesuaikan dengan kompetensi kemampuan mahasiswa.

Adapun kurikulum Ma'had alJami'ah sepenuhya diserahkan kepada masing-masing lembaga sesuai dengan karakteristik keunggulan yang dimiliki lembaga tersebut. Namunpun demikian, keluasan ini tetap memiliki acuan materi dalam struktur kurikulum yang mencakup materi dasar, materi kekhasan, dan pengabdian masyarakat. Secara terperinci yakni: Satu, Materi dasar meliputi kajian alQur'an, hadis, aqidah, akhlak, sejarah Islam dan bahasa arab (asing), Dua, Meteri Kekhasan yang menfokuskan pada kajian tematik Islam kontemporer dan kebangsaan dalam bentuk integralistik nilai-nilai ibadah mahdhah dan ghairu mahdhah, integralistik nilai nilai yang bersifat holistik dan profetik mengikuti jejak Rasulullah, para sahabat dan ulama salaf dalam berakhlak dan bermuamalah, serta membangun daya nalar kritis kreatif berkarakter islam washatiyah, Tiga, Program pengabdian masyarakat meliputi Spiritual Journey (safari dakwah) dan Camping dakwah (Saufi, 2018). 
Resminya perubahan status dari STAIN menjadi IAIN Pekalongan pada tahun 2017 berdampak bagi para pengelola akademik untuk meningkatkan kapasitas lembaga baik secara kuantitas maupun secara kualitas. Dan juga keluarnya intruksi dari Kementrian Agama Republik Indonesia Direktorat Jenderal Pendidikan Islam untuk segera menyelenggarakan pesantren kampus (ma'had al-jami'ah) di Perguruan Tinggi Keagamaan Islam $^{3}$. Sehubungan dengan hal tersebut pada tahun 2018 IAIN Pekalongan mendirikan Unit Layanan Ma'had al-Jami' ah yang berfungsi sebagai unit pembinaan mahasiswa dalam memperkuat dasar-dasar dan wawasan keagamaan keislaman sekaligus mengembangkan keterampilan tradisi akademik dan karakter mahasiswa yang berkeadaban (Interview, 13 Agustus 2021). Aktualisasi Ma'had al-Jami'ah IAIN Pekalongan menjadi perhatian serius mengingat era revolusi industri 4.0 dan kebijakan kampus merdeka belajar yang memiliki karakter spesifikasi profesi dan digitalisasi bersentuhan dengan dinamika kehidupan mahasiswa yang berimbas pada cara pandang mahasiswa dalam menyikapi hidup beragama.

Sesuai dengan tujuan kebijakan kampus merdeka belajar untuk meningkatkan lulusan, baik soft skills maupun hard skills terwujud dalam program kegiatan Ma'had al-Jami'ah IAIN Pekalongan. Dalam hal pembinaan Ma'had al-Jami'ah bekerjasama dengan Pondok Pesantren di Kota/Kabupaten Pekalongan, menjalin kerjasama dengan organiasi atau lembaga sosial keagamaan seperti Forum Komunikasi Madrasah Takmiliyah. Adapun Program Ma'had al-Jami'ah antara lain:
1. Program Dirasah Ma'had al-Jami'ah terbagai dalam tiga bentuk program yaitu Program Dirasah Tahsin al-Qur'an, Dirasah Tahfidz, dan Dirasah Kitab Turast. Secara terperinci sebagai berikut:

a. Program Dirasah Tahsin al-Qur'an

Program Dirasah Tahsin adalah program pembinaan peningkatan kemampuan mahasiswa dalam bidang membaca dan menulis al-Qur'an agar baik dan benar sesuai dengan kaedah ilmu tajwid. Program Dirasah Tahsin diperuntukan untuk mahasiswa baru yang tidak lulus dalam ujian Placement Test Baca Tulis al-Qur'an di awal masuk menjadi mahasiswa. Program Dirasah Tahsin bersifat wajib bagi mahasiswa baru. Hal ini penting karena Program Dirasah Tahsin merupakan penunjang utama kemampuan dasar yang harus dikuasai mahasiswa sebelum mendalami ilmu-ilmu keislaman lainya. Program ini sekaligus sebagai standarisasi kompetensi lulusan IAIN Pekalongan (Interview, 13 Agustus 2021).

Dalam pelaksanaanya program Dirasah Tahsin ditempuh selama satu (1) tahun atau dua (2) semester dengan cakupan materi pendalaman ilmu tajwid, ilmu gharibul kalimat, kitabah, praktek membaca dan menulis surat alQur'an. Adapun pelaksana program Dirasah Tahsin adalah pemitraan dengan pengajar yang memiliki kompetensi bidang baca tulis al-Qur'an yang dibuktikan dengan syahadah qira'at. Hasil nilai kelulusan Program Dirasah Tahsin ini penting bagi mahasiswa karena sebagai pra-syarat dalam mengajukan praktikum,

\footnotetext{
${ }^{3}$ http://diktis.kemenag.go.id > file > dokumen
} 
munaqosah hingga skripsi (Huda et al., 2020).

b. Program Dirasah Tahfid al-Qur'an

Program Dirasah Tahfid alQur'an adalah program pembinaan peningkatan kemampuan mahasiswa dalam menghafal al-Qur'an secara tartil. Mahasiswa baru yang lulus dalam ujian Placement Test Baca Tulis al-Qur'an wajib memilih salah satu program yaitu Dirasah Tahfid atau Dirasah Kitab Turast. Mahasiswa yang sudah memiliki kemampuan membaca dan menulis al-Qur'an dengan baik dan benar dibekali dengan pembinaan menghafal al-Qur'an. Program Dirasah Tahfid sekaligus mengakomodir mahasiswa yang sudah memiliki hafalan al-Qur'an atau mahasiswa tahfid.

Program Dirasah Tahfid dilaksanakan selama satu (1) tahun atau dua(2) semester dengan cakupan hafalan juz amma dan surat-surat pilihan serta pembinaan seni tilawah al-Qur'an. Adapun pelaksana Program Dirasah Tahfid adalah pengajar yang memiliki kompetensi hafalan 30 juz (hafid dan hafidzah) yang dibuktikan dengan syahadah tahfid (Huda et al., 2020).

\section{c. Program Dirasah Kajian Kitab Turast}

Program Dirasah Kitab Turast adalah kegiatan penunjang pendalaman dan penguatan kompetensi mahasiswa dalam bidang kajian ilmu-ilmu keislaman. Program Dirasah Kitab Turast ditujukan kepada mahasiswa baru yang lulus pada ujian Placement Test Baca Tulis al-Qur'an. Adapun kurikulum pembelajaran Program Dirasah Kitab Turast diorentasikan pada bidang aqidah, fiqih, akhlak, nahwu-shorof. Program Dirasah Kitab turast dimaksudkan untuk memastikan bahwa lulusan IAIN Pekalongan dapat membaca, memahami kitab turast serta mampu mengamalkanya sehingga mahasiswa memilii kepribadian yang alim dan berakhlak.

Program Dirasah Kitab Turast dilaksanakan selama satu (1) tahun atau dua (2) semester. Program Dirasah Kitab Turast terbagi dalam tiga bentuk tingkatan dengan spesifikasi kajian yang menyesuaikan tingkatan, tingkatan tersebut yaitu Tingkat Ula dengan materi kitab Aqidatul Awam, Safinatun Najah, dan kitab Taisirul Khalaq. Tingkat Wustha dengan materi kitab Bayanul Mufid, Fathul Qarib, Adabul Alim wal Muta'alim. Sedangkan Tingkat Ulya materi kajian kitab Jauharut Tauhid, Fathul Mu'in, dan kitab Salalimul Fudhola'(Huda et al., 2020).

2. Program Pondok Pesantren Mitra Ma'had al-Jami'ah

Program Pondok Pesantren Mitra Ma'had al-Jami'ah adalah program pendidikan, pendalaman ilmu-ilmu keislaman dan pembinaan pengamalan praktik keagamaan bagi mahasiswa yang memperoleh beasiswa bidikmisi atau beasiswa KIP dengan dititipkan di Pondok Pesantren selama satu (1) tahun. Program pendidikan pesantren ini bermaksud mengembangkan potensi mahasiswa dalam spiritual dan emosionalnya seta kecerdasan lainya yang sudah dibangun berpuluh puluh tahun di pondok pesantren sebagai pusat kajian keislaman sekaligus teruji dalam praktik pengamalan keagamaan yang moderat. 
Adapun pondok pesantren mitra berjumlah sebelas (11) yaitu antara lain, Pondok Pesantren (PP) alUstmani Gejlik Kajen, PP. az-Zabur Jl. Diponegoro Kajen, PP. Anwarul Mubarok Jl Karya Bakti Medono, PP. Ishlahut Tholabah Banyurip, PP. Al Hadi min Ahli Sunnah Panjang Wetan, PP. Darul Ishlah Panjang Wetan, PP. Al-Masyhad Mambaul Falah Sampangan, PP. Roudlotuth Tholibin Duwet, PP. Al-Qutub Wonopringgo, PP. An-Nur Bojong, PP. Hidayatul Mubtadiin Sampangan. Mahasiswa di Pondok Pesantren selain belajar sesuai kurikulum kekhasan masing masing pesantren, dari Ma'had al-Jami'ah juga memberikan kurikulum titipan. Kurikulum titipan Ma'had al-Jami'ah ini sebagai acuan pelaksanaan kegiatan pembelajaran sekaligus sinkronisasi target capaian pembelajaran (Abadi et al., 2019).

3. Program Praktikum Ibadah Tilawah

Program praktikum Ibadah dan Tilawah adalah program penunjang kompetensi mahasiswa lulusan IAIN Pekalongan. Output penguasaan membaca al-Qur'an dengan baik dan benar sesuai ilmu qira'at, kemampuan menulis dan menghafal al-Qur'an juz 30, kemampuan praktik ibadah mulai dari bab bersuci, sholat, hingga doa dengan baik sesuai petunjuk syariat, merupakan kemampuan dasar yang harus dimiliki oleh mahasiswa sekaligus sebagai distingsi lulusan IAIN Pekalongan. Pembinaan tersebut tidak sekedar pengamalan ibadah melainkan mengupas pemahaman dari aspek hukum fikihnya (rukun, syarat, wajib, sunnah, haram) yang terkandung didalam setiap amalan tersebut (Interview, 11 September 2021)
Mahasiswa yang ingin mengikuti praktikum ibadah tilawah harus memenuhi persyaratan administrasi salah satunya yaitu memiliki syahadah lulus program Dirasah Ma'had al-Jami'ah. Program praktikum ibadah tilawah diselenggarakan setiap semester dengan jumlah kuota 1000 mahassiwa. Adapun penguji praktikum ibadah tilawah adalah dosen IAIN Pekalongan yang diseleksi kompetensinya oleh Ma'had al-Jami'ah dalam hal ini penguji memiliki kemampuan keahlian dan penguasan dalam bidang ilmu-ilmu keislaman (Abadi et al., 2021)

4. Program Mahasiswa Cendekia

Program Mahasiswa Cendekia adalah program yang membantu dan menawarkan mahasiswa IAIN Pekalongan yang berpotensi untuk menjadi mahasiswa unggul dalam hal akademis, wawasan dan sikap keislaman yang kokoh dalam akar kenusantaraan dan siap menjadi agen moderasi dalam konteks global. Adapun pemaknaan unggul secara akdemisi adalah capaian mahasiswa cendekia untuk berprestasi dalam hal penulisan karya ilmiah dan presentasi ilmiah. Namun secara pragmatis mahasiswa cendekia juga ikut aktif berprestasi di mata kuliah sesuai jurusanya masing-masing.

Dengan demikian tujuan utama program mahasiswa cendekia adalah melaksanakan kegiatan yang berbasis bi'ah pondok pesantren befokus pada pendalaman kompetensi akademis dan pengayaan literatur keislaman sesuai keprodian. Kurikulum program cendekia mengarusutamakan 3 Maharoh yaitu 1) Metode Ilmiah, 2) Kajian Keislaman, 3) Bahasa Asing. 
Program Mahasiswa Cendekia ditempuh selama satu (1) tahun dan diasramakan agar proses pembinaan fokus dan terarah. Adapun rekruitmen peserta melalui proses seleksi yaitu seleksi administrasi dan seleksi potensi akademik, potensi kebahasaan, dan potensi wawasan keislaman serta potensi membaca memahami teks kitab kuning (Priyanto et al., 2020).

\section{SIMPULAN}

Sebagaimana kebijakan visioner kampus merdeka belajar untuk menfasilitasi program program experintial learning bagi mahasiswa agar mahasiswa mampu mengembangkan potensinya, Ma'had al-Jami'ah IAIN Pekalongan menyongsong kebijakan tersebut dengan mengoptimalisasikan pelayanan berbasis penguatan ilmu-ilmu keislaman. Disamping capaian pembelajaran tingkat jurusan atau fakultas, program-program yang diadakan di Ma'had al-Jami'ah IAIN Pekalongan melalui pengembangan kurikulum tidak lain untuk memperkaya capaian pembelajaran lulusan sesuai amanah kebijakan kampus merdeka belajar. Melalui kerjasama dengan pondok pesantren dan forum komunikasi diniyah takmiliyah dalam hal pembinaan pemahaman ilmu ilmu keislaman merupakan bentuk pengintegrasian sistem pembelajaran sehingga menghasilkan cara pandang mahasiswa yang moderat, berfikir ilmiah, kritis, terarah, tanpa menghilangkan akar budaya dan semangat spiritual melainkan justru mengkomunikasikan dalam bangunan keilmuan yang penuh dengan keadaban.

Namun memang disadari penerapan kebijakan kampus merdeka belajar di Ma'had al-Jami' ah IAIN Pekalongan belum maksimal. Dalam Permendikbud No 3
Tahun 2020 pasal 15 ayat 1 bentuk kegiatan pembelajaran kampus merdeka belajar antara lain pertukaran pelajar, magang/praktik kerja, penelitian riset, kuliah kerja nyata tematik, studi/proyek independen, kegiatan wirausaha, proyek kemanusiaan, dan penelitian/riset. Untuk itu, Ma'had al-Jami'ah IAIN Pekalongan kedepan perlunya mensinergitaskan sistem kerja antar unit dan lembaga di lingkungan civitas akademik IAIN Pekalongan sehingga tercipta suasanya harmonisasi keilmuan dan menghasilkan kualitas pembelajaran sejalan dengan kebijakan kampus merdeka belajar di Ma'had alJami'ah.

\section{Daftar Pustaka}

Abadi, K., Mufid, M., Arifin, J., \& Priyanto, A. (2021). Buku Panduan Praktikum Ibadah Tilawah Ma'had Al-Jami'ah. Pekalongan: IAIN Pekalongan

Abadi, K., Mufid, M., Makmun, \& Hidayat, M. M. (2019). Pedoman Pelaksanaan Mitra Kerja Pendidikan Pondok Pesantren bagi Mahasiswa Penerima Bidikmisi Ma'had aljami'ah. Pekalongan: IAIN Pekalongan

Bahar, H., \& Herli Sundi, V. (2020). Merdeka Belajar Untuk Kembalikan Pendidikan Pada Khittahnya. PROSIDING SAMASTA Seminar Nasional Bahasa Dan Sastra Indonesia, 115-122.

Baro'ah, S. (2020). Kebijakan Merdeka Belajar Sebagai Peningkatan Mutu Pendidikan. Jurnal Tawadhu, 4(1), 1063-1073. 
Direktorat Jenderal Pendidikan Tinggi

Islam Pendidikan Islam Kementerian. (2021). Penyelenggaraan Ma' had al-jami 'ah di Perguruan Tinggi Keagamaan Islam Negeri Direktorat Pendidikan Tinggi Islam Direktorat Jenderal Pendidikan Islam. Jakarta: Kementerian Agama

Dirjen Dikti Kemendikbud. (2020). Buku Panduan Pelayanan Merdeka Belajar dan Kampus Merdeka. Merdeka Belajar-Kampus Merdeka, 1-33. http://dikti.kemdikbud.go.id/wpcontent/uploads/2020/04/BukuPanduan-Merdeka-Belajar-KampusMerdeka-2020

Hafid, \& Mahsun. (2020). The Concept Of Independent Learning And The STAI Al-Hamidiyah Bangkalan. Al-Fikrah, 3(1), 108-124.

Huda, M., Hidayat, M. M., Makmun, Mufid, M., Abadi, K., Yazid, M. A., Fauzi, R., Arifin, J., \& Priyanto, A. (2020). Buku Panduan Ma'had alJami'ah IAIN Pekalongan.

Islam, D. J. P. (2011). Kementerian Agama RI. Intruksi Penyelenggaraan Pesantren Kampus, 12(3), 4-6.

Jumaeda, S. (2017). Ma'had al-Jamiah di Institut Agama Islam Negeri Ambon. Al-Iltizam, 2(1), 1-11.

KemendagRI. (2014). Pedoman

Penyelenggaraan Madrasah Diniyah Taklimiyah. 67.

Khoirin, D. (2021). Pengembangan Kurikulum Pendidikan Agama Islam 2013 Integratif dalam Menghadapi Era Society 5.0. TADRIS: Jurnal Pendidikan Islam, April, 83-94. https://doi.org/10.19105/tjpi.v16i1.41 09
Moleong, L. J. (2017). Metodologi penelitian kualitatif (Revisi). Bandung: PT Remaja Rosdakarya.

Prakoso, B. H., Ramdani, Z., \& Rahmah, B. (2021). Teacher' S Perception On Merdeka Belajar Policy. Indonesian Journal of Educational Assessment, 3(2), 128-137.

Priyanto, A., Yazid, M. A., Arifin, J., \& Mufid, M. (2020). Buku Panduan Mahasiswa Cendekia Ma'had AlJami'ah.

Saufi, M. (2018). Keputusan Direktur Jenderal Pendidikan Islam Nomor 4052 Tahun 2018. Petunjuk Teknis Penyelenggaraan Madrasah Diniyah Takmiliyah Al-Jami'ah, 2(17), 227249.

Siregar, N., Sahirah, R., \& Harahap, A. A. (2020). Konsep Kampus Merdeka Belajar di Era Revolusi Industri 4.0. Fitrah: Journal of Islamic Education, 1(1), 141-157.

Suardi. (2018). Implementasi Program Ma ' Had Dalam Meningkatkan Wawasan Keislamaan Mahasiswa (Studi Penelitian pada Rusunawa UIN arRaniry Banda Aceh). Skripsi.

Subana, M. (n.d.). dkk. 2001. dasar-dasar penelitian ilmiah. Bandung: Pustaka Setia.

Ulyan, M., Budiyanti, N., \& Adi Nugraha, S. (2020). Islamic Education Based on Arabic Pegon Letters in Madrasah Diniyah Al Barokah Watuagung Tambak Banyumas. Iqra' Kajian Ilmu Pendidikan, 5(1), 133-144.

Widiyono, A., \& Irfana, Saidatul, K. F. (2021). Implementasi Merdeka Belajar melalui Kampus Mengajar 
Perintis di Sekolah Dasar. Metodik

Didaktik: Jurnal Pendidikan Ke-SD-

An, 16(2), 102-107.

https://doi.org/10.17509/md.v16i2.30

125

Yamin, M., \& Syahrir, S. (2020).

Pembangunan Pendidikan Merdeka

Belajar (Telaah Metode

Pembelajaran). Jurnal Ilmiah

Mandala Education, 6(1), 126-136.

https://doi.org/10.36312/jime.v6i1.11

21 